\title{
An estimation of staffing requirements in primary care in Oman using the Workload Indicators of Staffing Needs method
}

Nazar Mohamed, ${ }^{1}$ Ahmed Al-Qasmi, ${ }^{2}$ Said Al-Lamki, ${ }^{3}$ Mohamed Bayoumi ${ }^{4}$ and Ali Al-Hinai ${ }^{5}$

${ }^{1}$ Human Resources Planning, ${ }^{2}$ Planning and Studies Department, ${ }^{3}$ Primary Health Care Department, ${ }^{4}$ Health Information Department, ${ }^{5}$ Planning Affairs Department, Ministry of Health, Muscat, Oman (Correspondence to: Nazar A. Mohamed: elfakin@gmail.com)

\begin{abstract}
Background: Oman is a high-income country having a relatively small population scattered over large sparsely populated areas. This presents challenges to the provision of health services. It is important to ensure that all health facilities at all levels of care have the right number and skills mix of health workers to deliver quality health care.

Aims: The main aim was to develop national staffing norms to ensure adequate numbers, appropriate skills mix and equitable distribution of health professionals in primary health care ( $\mathrm{PHC}$ ) using the workload indicators of staffing needs (WISN) method.

Methods: All types of PHC services were itemized (promotive, preventive, curative, and rehabilitative and support services). We used 2014 data from the health information system and the human resources management information system to develop staffing norms using the WISN method. First we set the norms based on the national average for the activity standards, then simulated the norms in Muscat governorate, which has $32 \%$ of the population.

Results: We calculated the required numbers of GPs and specialists for PHC centres providing core as well as core and supplementary services and the expected annual outpatient attendance. The simulation showed that doctors were less workload stressed (WISN ratio 1.02) than nurses (WISN ratio 0.66) on average, although some variations between health centres were noted.
\end{abstract}

Conclusions: Additional parameters (e.g. planned new services; local disease profile; change in health policies) may be added in future to re-adjust the calculation method once the health services mapping and human resources for health profiles for each governorate is completed.

Keywords: health services, human resources, Oman, WISN, workload

Citation: Mohamed N; Al-Qasmi A; Al-Lamki S; Bayoumi M; Al-Hinai T. An estimation of staffing requirements in primary care in Oman using the Workload Indicators of Staffing Needs methods. East Mediterr Health J. 2018;24(9):823-829. https://doi.org/10.26719/2018.24.9.823

Received: 19/07/17; accepted: 21/03/18

Copyright (c) World Health Organization (WHO) 2018. Some rights reserved. This work is available under the CC BY-NC-SA 3.0 IGO license (https:// creativecommons.org/licenses/by-nc-sa/3.o/igo).

\section{Introduction}

The Sultanate of Oman is a high-income country having a relatively small population of nearly four million, of which $42.2 \%$ are expatriates or non-nationals, scattered over large areas of sparsely populated settlements which present challenges to the provision of health services (1).

The Ministry of Health recognized the importance of ensuring that all health facilities at all levels of health care have the right number and skills mix of health workers to deliver quality of health care to the population served. This was stated clearly in Oman Health Vision 2050 that called for quality care and sustained health (1). As a result, the Directorate General of Planning and Studies and the Directorate General of Primary Health Care worked jointly in adapting and adjusting the workload indicators of staffing needs (WISN) method. This was developed by the World Health Organization (WHO) to develop the national standards for primary health care institutions to assist health planners and managers to appropriately recruit and distribute health workers across geographical locations and primary health care (PHC) facilities (2) and has been used by many countries in different settings (36). It calculates the number of health workers per health facility based on the workload by providing gap/excess between the current and required number of health workers, and it also provides a proxy measure, the WISN ratio, to assess workload pressure on health workers.

Our objective is to develop national staffing norms to ensure adequate numbers, appropriate skills mix and equitable distribution of professionals working in $\mathrm{PHC}$ in Oman using the WISN method. This paper describes the process of formulating the national norms and presents the key findings and some of the limitations.

\section{Methods}

First, a joint team from the Directorate General of Planning and Studies and the Directorate General of Primary Health Care listed all types of primary health care services provided currently. This list comprises 42 services that encompass promotive, preventive, curative, and rehabilitative and support services. Next, the team categorized the services into three packages of services based on the location and catchment population served. These are: core services (basic), supplementary services, and complementary services (Table 1). Hence, each health facility will provide a defined package of primary health care ser- 


\begin{tabular}{lll}
\hline \multicolumn{2}{l}{ Table $\mathbf{1}$ List of health service packages provided at primary health care health facilities, Oman, 2014 } & Complementary \\
\hline Core (basic) & Supplementary & Delivery services \\
\hline Outpatient clinic & Acute care & Training facilities \\
Child health/vaccination & Infertility & Speciality clinic: \\
Antenatal \& postnatal care & Dermatology & Internal medicine \\
Birth spacing & Obstetrics \& gynaecology \\
Nutrition \& growth monitoring & General surgery \\
Care of the elderly & Orthopaedic \\
Counselling \& health education & Nephrology \\
Community outreach services \& activities & Eye care \\
School health services & Ear, nose and throat (ENT) \\
Mental health care & Screening services \\
Noncommunicable diseases: & Ultrasonography \\
Diabetes \& endocrinology & Physiotherapy \\
Cardiac diseases & Environmental health \\
Asthma \& chronic respiratory diseases & \\
Dental care & \\
Laboratory investigations & \\
Radiology (X-ray) & \\
Dispensing of drugs & \\
Medical records & \\
Triage & \\
Observational beds & \\
Ambulance service & \\
\hline
\end{tabular}

vices within its catchment area.

TheWISN steps were followed in calculating the health service activity (activities performed by all members of the staff category and for which annual statistics are regularly collected) and the support activity (the important activities that support health service activities, performed by all members of the staff category but for which annual statistics are not regularly collected). Thus the health service activities of doctors, nurses, dentists, pharmacists, assistant pharmacists and laboratory technicians were listed, the activity standards (defined as the time necessary to perform an activity to acceptable professional standards in the local circumstances) and standard workloads (the amount of work within a health service component that one health worker can do in a year) (2) were set and calculated manually. It is worth mentioning that most the activity standards set for the health service activities of the general practitioner (GP) were 16 minutes per case, thus the team decided to take it as an average to develop the national norms. The same applied for the specialist (21 minutes per case).

The support activities for GPs were also identified (for health centres providing the core services as well as those providing core and supplementary services); the category allowance standard, defined as the allowance standard for support activities performed by all members of a staff category (2), was determined for both types of health centre $(17 \%$ for centres providing core activities and $23 \%$ for centres providing core and supplementary services); The category allowance factor (a multiplier used to calculate the total number of health workers required for health service and support activities) was then calculated (2). The category allowance factor was set as minimum and maximum (i.e. 1.2 and 1.3) to suit the context of the $\mathrm{PHC}$ institutions in terms of service package based on the formula:
Category allowance factor $=1 /[1-($ total category allowance standard/100)].

Some modifications to the WISN were made in order to ease the development of the national norms, e.g. setting the personal time allowance as $15 \%$ instead of calculating the individual allowance factor, taking the national average number of nurses per doctor at PHC level as 2.2 instead of applying the WISN for nurses, calculating the average visits per person per PHC facility per year 4.2. This average was determined using the data of the annual health report for 2014 (9546903 visits/2 260705 population) (7) and linking it to the catchment population.

The PHC institutions that provide the core services are staffed by GPs, while the PHC institutions that provide both the core and supplementary services are staffed by GPs plus specialists.

Where activities are shared between two cadres (e.g. vaccination of children where the child should first see the doctor and then go to the nurse to receive the vaccination), the activity standard was divided between the two cadres according to the time spent by each cadre. The Directorate General of PHC validated the main workload components and activity standards.

The data used to calculate the staffing norms were from 2014 (7) and extracted from the computerized records of the health information system and the human resources management (HRM) information system. The calculations were based on the PHC services utilization pattern in 2014, which showed that the average annual number of visits per person per PHC facility was 4.2 (7).

Although the staffing norms were made for all cadres working at PHC institutions, the calculations displayed in the results are attributed to doctors and nurses. The team first set the norms based on the national average of the activity standards, then simulated the norms in Muscat governorate (the capital) based on 2014 annual 
statistics. The WISN ratio was also calculated by dividing the current number of staff by the required number. A WISN ratio of 1.00 shows that current staffing is in balance with the staffing demands for the workload of the health facility. A WISN ratio of $>1.00$ is evidence of overstaffing in relation to the workload. Conversely, a WISN ratio of $<1.00$ indicates that the current number of staff is insufficient to cope with the workload (2). The smaller the WISN ratio, the greater the work pressure.

This methodology will inform human resources for health policy-makers and decision-makers and allow them to see whether the national standards are adhered to by $\mathrm{PHC}$ institutions.

\section{Results}

\section{National staffing norm for doctors (GPs and specialists)}

The calculated numbers of GPs and specialists for the PHC health centres providing core services as well as those providing core and supplementary services were based on the factors shown in Table 2; the averages shown are the national averages based on the 2014 annual statistics. The activity standard of the general practitioner (GP) was 16 minutes per case, while for the specialist was 21 minutes per case.

The required numbers of GPs and specialists for PHC health centres providing core as well as core and supplementary services are shown in Table 3. The expected values for annual outpatient attendance are the national averages based on the 2014 annual statistics and related to the catchment population. The average annual number of visits per person per PHC facility was 4.2 based on the PHC services utilization pattern.

\section{National staffing norms for nurses}

The joint team decided that the calculation at PHC facilities would be based on the average number of nurses per doctor at PHC level, i.e. 2.2, according to the 2014 figures (7); this is near to the average of 2.3 specified in Oman Health Vision 2050 (1). The required numbers of nurses for PHC health centres providing the core services as well as core and supplementary services are shown in Table 4. The variations in the number required were due to the catchment population in addition to the package of services provided in the health facilities.

The same method of calculation was used in the simulation for the health centres in Muscat governorate (the capital), which has $32 \%$ of the total population and encompasses the largest number of health facilities

\begin{tabular}{lr}
\hline Table 2 List of factors used to calculate numbers of GPs and specialists for primary health care centres, Oman, 2014 & Time \\
Factor & 212 \\
Total working days per doctor per year (after subtracting annual leave, national holidays, etc) & 5 \\
Total working days per week & 7 \\
Working hours per day & 35 \\
Total working hours per week & 1484 \\
Total working hours per year & $15 \%$ \\
Personal time allowance & \\
Average time per case for a GP (minutes) & 16 \\
Average time per case for a specialist (minutes) & 21 \\
\hline
\end{tabular}

ancludes meetings, trainings, supervision, responding to telephone calls, breaks, etc.

${ }^{b}$ Average time per case is the activity standard.

Table 3 The required numbers of general practitioners (GPs) and specialists for primary health care (PHC) centres providing core as well as core and supplementary services, Oman, 2014

\begin{tabular}{|c|c|c|c|c|}
\hline \multirow[t]{2}{*}{ Catchment population } & \multirow{2}{*}{$\begin{array}{l}\text { Expected annual outpatient } \\
\text { attendance for PHC core } \\
\text { services }\end{array}$} & \multirow{2}{*}{$\begin{array}{c}\text { Total hours per } \\
\text { year }^{\mathrm{a}}\end{array}$} & \multicolumn{2}{|c|}{ GPs required } \\
\hline & & & $\operatorname{Min}(1.2)^{b}$ & $\operatorname{Max}(1.3)^{b}$ \\
\hline & \multicolumn{4}{|c|}{ Centres providing core services } \\
\hline$\leq 5000$ & 13514 & 3604 & 3.0 & 3.0 \\
\hline $5001-10000$ & 27029 & 7208 & 6.0 & 6.0 \\
\hline \multirow[t]{2}{*}{$10001-15000$} & 40543 & 10811 & 8.0 & 9.0 \\
\hline & \multicolumn{4}{|c|}{ Centres providing core $\&$ supplementary services } \\
\hline$\leq 5000$ & 56886 & 16443 & 8.0 & 5.0 \\
\hline $5001-10000$ & 68264 & 19731 & 9.0 & 6.0 \\
\hline $10001-15000$ & 79641 & 23020 & 11.0 & 7.0 \\
\hline
\end{tabular}

${ }^{a}$ This was used to calculate the total number of doctors needed to carry out the expected workload per catchment area population.

${ }^{b}$ Category allowance factor. 


\begin{tabular}{|c|c|c|c|}
\hline \multicolumn{4}{|c|}{$\begin{array}{l}\text { Table } 4 \text { Required numbers of nurses for primary health care } \\
\text { centres providing core and supplementary services, Oman, } \\
2014\end{array}$} \\
\hline \multirow[t]{2}{*}{ Catchment population } & \multirow{2}{*}{$\begin{array}{l}\text { Doctors } \\
\text { required }\end{array}$} & \multicolumn{2}{|c|}{ Nurses required } \\
\hline & & $1.2 \mathrm{a}$ & $1.3 b$ \\
\hline & \multicolumn{3}{|c|}{ Centres providing core services } \\
\hline$\leq 5000$ & 3 & 8 & 9 \\
\hline $5001-10000$ & 6 & 16 & 18 \\
\hline \multirow[t]{2}{*}{$10001-15000$} & 8 & 21 & 23 \\
\hline & \multicolumn{3}{|c|}{$\begin{array}{l}\text { Centres providing core \& } \\
\text { supplementary services }\end{array}$} \\
\hline $20001-25000$ & 13 & 34 & 37 \\
\hline $25001-30000$ & 15 & 40 & 44 \\
\hline $30001-35000$ & 18 & 48 & 53 \\
\hline
\end{tabular}

aCategory allowance factor (minimum).

${ }^{b}$ Category allowance factor (maximum).

compared with the other 10 governorates. A comparison of the national staffing norms for doctors and nurses with the existing staffing levels in Muscat governorate (for 2014) was made (Table 5). Overall, according to the average WISN ratio, doctors were less workload stressed (1.02) than nurses (0.66), although some variations between health centres were noticed (doctors range 0.62.3; nurses range 0.4-1.6).

\section{Discussion}

The WISN tool, after being adapted, was demonstrated to be useful in setting the national norms. It is also a dynamic tool whose use can be repeated on a frequent basis (depending on the availability of data) to improve the adequacy and distribution of health workers within governorate or across similar types of PHC facilities (based on the service package). The tool has been used in many countries and for different purposes. Ghana was among the pioneering countries to develop an evidenced-based staffing norm using the WISN tool (8). The overall purpose of the WISN study in Kenya was to inform development of human resources for health norms and standards (8). In Namibia, it has been applied to determine staffing requirements to rationalize staff requirements for nurses, doctors, pharmacists and pharmacist assistants (3). The pilot phase in Botswana provided an excellent opportunity to examine the total workload of the facilities using the WISN results for several health worker categories before national roll-out (8). In East Africa, the method has been used in Tanzania to determine the staffing needs for quality prenatal care for nurse officers, nurse midwives and nursing assistants (9). It was also used to calculate the staffing requirements for medical officers, nurses and laboratory staff in Kenya (10). This method was initially used to determine the nursing staff requirements in Lacor, a private, not-for-profit hospital in Northern Uganda in 2005 (4). It has also been used in India and Bangladesh (5,11).

The application of WISN in Namibia revealed that the process is flexible and should be designed to fit the goals and scope of the WISN application (3). It was suggested that policy-makers and facility managers could use the WISN method to estimate health worker requirements for a range of needs and scenarios, including making staff adjustments in response to implementation of new services, decentralization, or reconfiguration of primary care services (3).

The simulation of the staffing norms using the 2014 data of Muscat governorate assisted in comparing the existing situation in the PHC health facilities against the national norms, and identifying the staffing equity across the governorate. It also showed an overall shortage in the number of nurses and a slight surplus for doctors although some variations between the health centres were noticed. When calculating the WISN ratio, it showed that some health centres work under great workload stress compared to others.

One of the limitations concerned the estimates that were used to calculate the required staffing; these were linked mainly to the package and pattern of health services provided to the current population, which might not be applicable to the future population. Thus the estimates will need to be frequently adjusted in line with new developments.

\section{Conclusion}

Additional parameters could be added in the future to re-adjust the calculation method once the health services mapping and human resources for health profiles for each governorate is completed. Examples of these parameters include planned new services; the trends in health services utilization pattern by different population groups; the optimal or desired level of skills mix of health workers per qualification and for each type of health facility; the local disease profile; changes in health policies (such as shifting some services from the supplementary to the core services); demographic characteristics and health needs of the population served; health workforce growth; and advances in health technology and new therapies, which sometimes alter the average time spent, e.g. for consultations or carrying out procedures.

Funding: None.

Competing interests: None declared. 
Table 5 Status in Muscat governorate according to current situation (CS) and national primary health care (PHC) norms, 2014

\begin{tabular}{|c|c|c|c|c|c|}
\hline Health centre & Item & $\begin{array}{c}\text { Catchment area } \\
\text { population }\end{array}$ & No. of outpatient visits & No. of doctors & No. of nurses \\
\hline \multirow[t]{2}{*}{ Siya } & CS & 3679 & 16275 & 6 & 6 \\
\hline & PHC norm & $\leq 5000$ & 13500 & 3 & 7 \\
\hline \multirow[t]{2}{*}{ Mutrah } & CS & 19798 & 47482 & 15 & 15 \\
\hline & PHC norm & $\leq 20000$ & 54000 & 12 & 26 \\
\hline \multirow[t]{2}{*}{ Ash Shaadi } & $\mathrm{CS}$ & 37540 & 92734 & 14 & 24 \\
\hline & PHC norm & $\leq 40000$ & 108000 & 23 & 50 \\
\hline \multirow[t]{2}{*}{ Al Amrat } & CS & 19325 & 77002 & 15 & 20 \\
\hline & PHC norm & $\leq 20000$ & 54000 & 12 & 26 \\
\hline \multirow[t]{2}{*}{ Al Mazari } & CS & 2865 & 14153 & 5 & 7 \\
\hline & PHC norm & $\leq 5000$ & 13500 & 3 & 7 \\
\hline \multirow[t]{2}{*}{ Yiti } & CS & 4429 & 23203 & 5 & 11 \\
\hline & PHC norm & $\leq 5000$ & 13500 & 3 & 7 \\
\hline \multirow[t]{2}{*}{ Al Khawd } & CS & 41145 & 101934 & 15 & 27 \\
\hline & PHC norm & $\leq 45000$ & 121500 & 26 & 57 \\
\hline \multirow[t]{2}{*}{ Wadi Al Arbiyin } & CS & 560 & 1118 & 3 & 3 \\
\hline & PHC norm & $\leq 5000$ & 13500 & 3 & 7 \\
\hline \multirow[t]{2}{*}{ As Sifah } & CS & 1969 & 9390 & 3 & 6 \\
\hline & PHC norm & $\leq 5000$ & 13500 & 3 & 7 \\
\hline \multirow[t]{2}{*}{ Bamah } & CS & 3416 & 1265 & 4 & 6 \\
\hline & PHC norm & $\leq 5000$ & 13500 & 3 & 7 \\
\hline \multirow[t]{2}{*}{ Al Wadi Al Kabeer } & CS & 17474 & 42747 & 13 & 17 \\
\hline & PHC norm & $\leq 20000$ & 54000 & 12 & 26 \\
\hline \multirow[t]{2}{*}{ Al Mabeela } & CS & 30274 & 99929 & 16 & 19 \\
\hline & PHC norm & $\leq 35000$ & 94500 & 20 & 44 \\
\hline \multirow[t]{2}{*}{ Ruwi } & CS & 18398 & 47186 & 14 & 19 \\
\hline & PHC norm & $\leq 20000$ & 54000 & 12 & 26 \\
\hline \multirow[t]{2}{*}{ As Seeb } & CS & 19473 & 70243 & 13 & 22 \\
\hline & PHC norm & $\leq 20000$ & 54000 & 12 & 26 \\
\hline \multirow[t]{2}{*}{ Al Ghoubra } & CS & 31036 & 59965 & 16 & 18 \\
\hline & PHC norm & $\leq 35000$ & 94500 & 20 & 44 \\
\hline \multirow[t]{2}{*}{ Al Azaiba } & CS & 16086 & 50107 & 14 & 23 \\
\hline & PHC norm & $\leq 20000$ & 54000 & 12 & 26 \\
\hline \multirow[t]{2}{*}{ Al Wattyah } & CS & 27918 & 58339 & 14 & 17 \\
\hline & PHC norm & $\leq 30000$ & 81000 & 18 & 40 \\
\hline \multirow[t]{2}{*}{ Al Khuwayr } & CS & 34055 & 73448 & 16 & 24 \\
\hline & PHC norm & $\leq 35000$ & 94500 & 20 & 44 \\
\hline \multirow[t]{2}{*}{ An Nahdah } & CS & 18895 & 94522 & 16 & 21 \\
\hline & PHC norm & $\leq 20000$ & 54000 & 12 & 26 \\
\hline \multirow[t]{2}{*}{ South Al Mabeela } & CS & 20244 & 98106 & 18 & 22 \\
\hline & PHC norm & $\leq 25000$ & 67500 & 15 & 33 \\
\hline \multirow[t]{2}{*}{ Al Mawaleh } & CS & 23106 & 91245 & 19 & 19 \\
\hline & PHC norm & $\leq 25000$ & 67500 & 15 & 33 \\
\hline \multirow[t]{2}{*}{ Al Ansab } & CS & 9593 & 70729 & 14 & 21 \\
\hline & PHC norm & $\leq 10000$ & 27000 & 6 & 13 \\
\hline Hai Al Mina & CS & 6167 & 26542 & 13 & 21 \\
\hline & PHC norm & $\leq 10000$ & 27000 & 6 & 13 \\
\hline Al Hail & $\mathrm{CS}$ & 19136 & 72329 & 13 & 24 \\
\hline 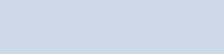 & PHC norm & $\leq 20000$ & 54000 & 12 & 26 \\
\hline
\end{tabular}




\begin{tabular}{|c|c|c|c|c|c|}
\hline Health centre & Item & $\begin{array}{l}\text { Catchment area } \\
\text { population }\end{array}$ & No. of outpatient visits & No. of doctors & No. of nurses \\
\hline \multirow[t]{2}{*}{ Muscat } & CS & 21698 & 67880 & 14 & 17 \\
\hline & PHC norm & $\leq 25000$ & 67500 & 15 & 33 \\
\hline \multirow[t]{2}{*}{ North Al Mawaleh } & CS & 21412 & 61315 & 13 & 24 \\
\hline & PHC norm & $\leq 25000$ & 67500 & 15 & 33 \\
\hline \multirow[t]{2}{*}{ Al Hajer } & CS & 9047 & 51103 & 10 & 18 \\
\hline & PHC norm & $\leq 10000$ & 27000 & 6 & 13 \\
\hline \multirow[t]{3}{*}{ Total } & CS & 469691 & 1479188 & 318 & 453 \\
\hline & PHC norm & & & 313 & 687 \\
\hline & $\begin{array}{l}\text { Average WISN } \\
\text { ratio }\end{array}$ & & & $1.02(318 / 313)$ & $0.66(453 / 687)$ \\
\hline
\end{tabular}

Workload indicators of staffing needs (WISN) ratio for each centre can be calculated by dividing the CS/PHC norm

\section{Estimation des besoins en personnel dans les soins de santé primaires à Oman : application de la méthode des indicateurs des besoins en personnel par rapport à la charge de travail}

\section{Résumé}

Contexte : Oman, un pays à revenu élevé, a une population relativement réduite, répartie sur de vastes zones faiblement peuplées. Ceci présente certaines difficultés quant à la prestation des services de santé. Il est important de faire en sorte que tous les établissements de santé, à tous les niveaux de soins, disposent d'effectifs et de compétences adéquats afin de pouvoir fournir des soins de santé de qualité.

Objectif : L'objectif principal était d'élaborer des normes de recrutement nationales afin de garantir des effectifs suffisants, une gamme de compétences adéquate et une répartition équitable des professionnels de soins de santé primaires (SSP) en se fondant sur la méthode des indicateurs des besoins en personnel par rapport à la charge de travail (méthode WISN ou Workload Indicators of Staffing Needs).

Méthodes : La liste détaillée de tous les types de services de SSP a été présentée (promotion, prévention, traitements, réadaptation et soutien). Nous nous sommes appuyés sur des données de 2014 tirées du système d'information sanitaire et de gestion des ressources humaines afin d'élaborer des normes de recrutement à l'aide de la méthode WISN. Nous avons d'abord défini les normes en fonction de la moyenne nationale des critères relatifs aux activités, puis nous avons simulé une mise en œuvre de ces normes dans le gouvernorat de Mascate, qui compte 32 \% de la population.

Résultats : Nous avons calculé le nombre nécessaire de médecins généralistes et de spécialistes pour les centres de SSP fournissant des services de base ainsi qu'une combinaison de services de base et de services supplémentaires et nous avons calculé ce que devrait être le taux annuel de consultations ambulatoires. La simulation a montré que les médecins étaient, en moyenne, moins victimes du stress dû à la charge de travail (ratio WISN de 1,02) que les personnels infirmiers (ratio WISN de 0,66), bien que des variations d'un centre de soins à un autre aient été constatées.

Conclusions : À l'avenir, d'autres paramètres (par exemple : nouveaux services prévus ; profil local des maladies ; modifications des politiques de santé) pourront être ajoutés afin d'effectuer un nouvel ajustement de la méthode de calcul après réalisation d'une cartographie des services de santé et des ressources humaines pour chaque gouvernorat.

$$
\text { تنقدير احتياجات التوظيف بالرعاية الصحية الأولية بعُمان باستخدام مؤشر ات حِمل العمل الحمل القاسمي، سعيد اللمكي، محمد بيومي، علي الهنائي }
$$

الخلفية: سلطنة عُمان من البلدان المرتفعة الدخل والتي فيها عدد قليل نسبيًا من السكان يتناثرون في مناطق شاسعة تقل فيها الكثافة السكانية. وهذا

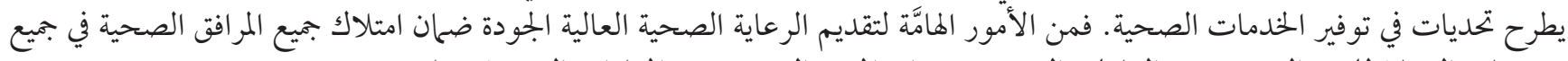

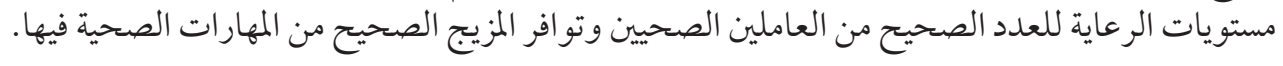

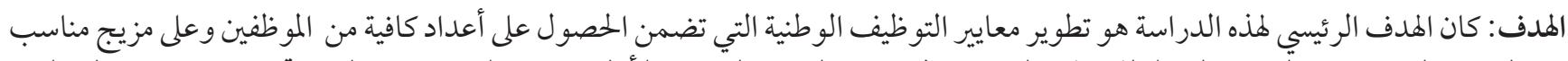

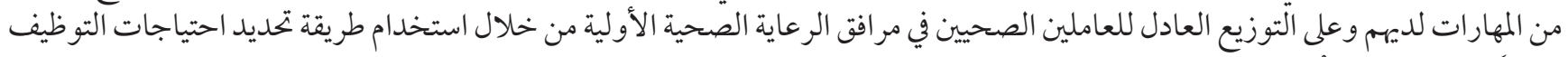

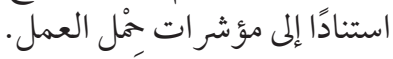




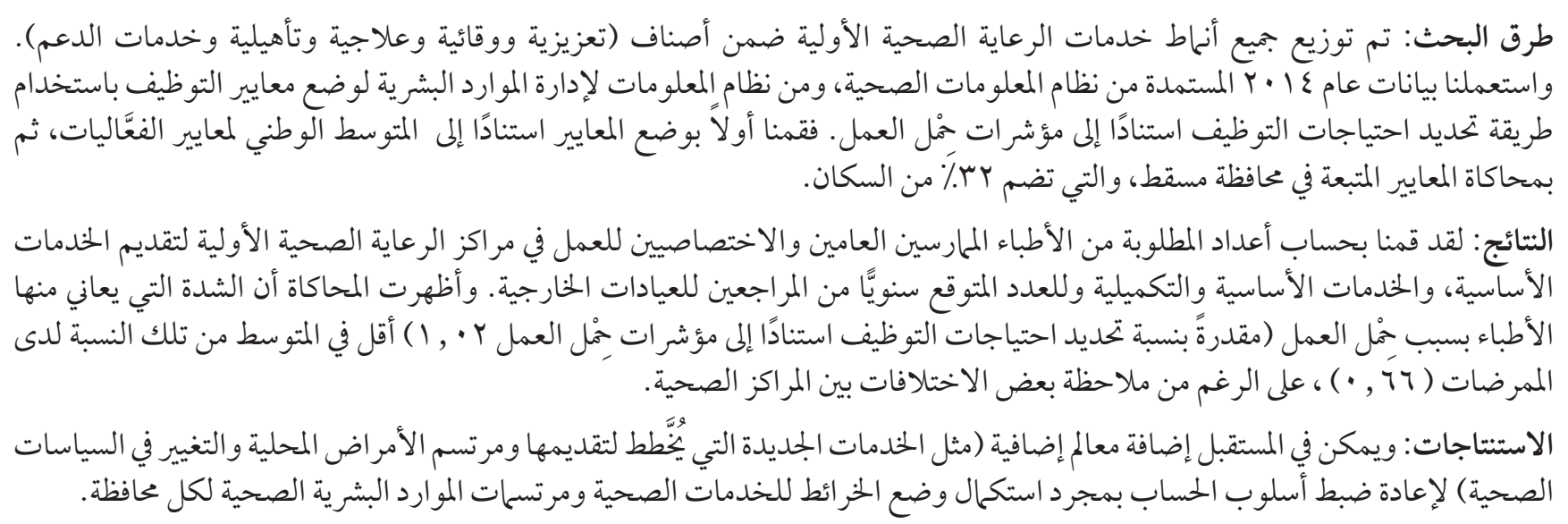

\section{References}

1. Oman health vision 2050. Muscat: Ministry of Health; 2014 (https://www.moh.gov.om/en/web/directorate-general-of-planning/ resources, accessed 5 April 2018).

2. Workload indicators of staffing need: user's manual. Geneva: World Health Organization; 2010.

3. McQuide PA, Kolehmainen-Aitken RL, Forster N. Applying the workload indicators of staffing need (WISN) method in Namibia: challenges and implications for human resources for health policy. Hum Resour Health. 2013;11(1):64. https://doi.org/10.1186/14784491-11-64 http://www.human-resources-health.com/content/11/1/64 PMID:24325763

4. Govule P, Mugisha JF, Katongole SP, Maniple E, Nanyingi M, Onzima RA. Application of workload indicators of staffing needs (WISN) in determining health workers' requirements for Mityana General Hospital, Uganda. Open Science. 2015;3(5):254-63. (http://www.openscienceonline.com/journal/ijphr, accessed 5 April 2018),

5. Hagopian A, Mohanty MK, Das A, House PJ. Applying WHO's 'workforce indicators of staffing need' (WISN) method to calculate the health worker requirements for India's maternal and child health service guarantees in Orissa State. Health Policy Plan. 2012 Jan;27(1):11-8. https://doi.org/10.1093/heapol/czroo7 PMID:21296847

6. Applying the WISN method in practice: case studies from Indonesia, Mozambique and Uganda. Geneva: World Health Organization; 2010.

7. Annual health report 2014. Muscat: Ministry of Health; 2015 (https://www.moh.gov.om/en/web/statistics/annual-reports, accessed 5 April 2018).

8. Workload indicators of staffing need (WISN): selected country implementation experiences. Geneva: World Health Organization; 2016. (Human Resources for Health Observer, Series No. 15; . http://apps.who.int/iris/bitstre am/10665/205943/1/9789241510059_eng.pdf, accessed 5 April 2018).

9. Nyamtema AS, Urassa DP, Massawe S, Massawe A, Lindmark G, Van Roosmalen J. Staffing needs for quality perinatal care in Tanzania. Afr J Reprod Health. 2008 Dec;12(3):113-24. http://www.bioline.org.br/pdf?rho8041 PMID:19435016)

10. Musau P, Nyongesa P, Shikhule A, Birech E, Kirui D, Njenga M, et al. Workload Indicators of Staffing Need method in determining optimal staffing levels at Moi Teaching and Referral Hospital. East Afr Med J. 2008 May;85(5):232-9. https://www.ajol.info/ index.php/eamj/article/view/9617/31100 PMID:18814533

11. Hossain B, Alam SA. Likely benefit of using workload indicators of staffing need (WISN) for human resources management and planning in the health sector of Bangladesh. Hum Resour Health. 1999;3:99-111 (http://www.who.int/hrh/en/HRDJ_3_2_03.pdf, last accessed 1 October 2017). 